\title{
Recuperative Brake System of the Porsche Taycan
}

\author{
Bernhard Schweizer $^{(\varpi)}$ und Martin Reichenecker ${ }^{(\varpi)}$
}

Dr. Ing. h.c. F. Porsche AG, Porschestraße 911, 71287 Weissach, Germany \{bernhard.schweizer, martin.reichenecker\} @porsche.de

Unfortunately, the translation of the script was not available for printing. The German original version is on page 28 . 